\title{
Stereospecific Synthesis of Two Isomers of $(4,8)$ - Dimethyldecanal: The Aggregation Pheromone of Tribolium spp
}

\author{
Paulo H.G. Zarbin ${ }^{*}$, Wellington de O. Cruz ${ }^{\mathrm{b}}$, and J. Tércio B. Ferreira ${ }^{\mathrm{\dagger}}$ \\ a Departamento de Química, Universidade Federal do Paraná, C.P. 19081, \\ 81531-990 Curitiba - PR, Brazil; e-mail: pzarbin@quimica.ufpr.br; \\ ${ }^{\mathrm{b}}$ Departamento de Química, Universidade Federal de Uberlândia, \\ Uberlândia, $M G$ - Brazil; \\ ${ }^{\mathrm{c}}$ Departamento de Química, Universidade Federal de São Carlos, \\ São Carlos - SP, Brazil
}

Received: December 19, 1997

\begin{abstract}
Uma síntese estereoespecífica para dois estereoisômeros, $(4 R, 8 S)$ e $(4 S, 8 S)$, do 4,8-dimetildecanal (1), entre os quatro possíveis, é descrita em apenas três etapas. A etapa chave emprega a reação de acoplamento dos tosilatos (3) e (3a), obtidos do $(R)$ - e $(S)$-citronelol, com o reagente de Grignard preparado a partir do $(S)-(+)-1$-bromo-2-metilbutano (4) comercial.

A straightforward stereospecific synthesis of two stereoisomers, $(4 R, 8 S)$ and $(4 S, 8 S)$, of 4,8-dimethyldecanal (1), out of four possible isomers, is described. The key step employs the coupling reaction of tosylates (3) and (3a), which are obtained from $(R)$ - and $(S)$ - citronellol, with the chiral Grignard reagent prepared from comercial $(S)-(+)-1$-bromo-2-methylbutane (4).
\end{abstract}

Keywords: 4,8-dimethyldecanal, Tribolium spp, asymmetric synthesis, pheromone

\section{Introduction}

The red flour beetle Tribolium castaneum and the confused beetle Tribolium confusum are notorious pests of various stored foodstuffs which particularly consume the small fragments of cereal seeds and related products ${ }^{1}$. In 1980 Suzuki identified and then synthesized the aggregation pheromone common to both species of Tribolium, the 4,8-dimethyldecanal (1) ${ }^{2,3}$. In 1983 Mori and co-workers ${ }^{4,1}$ established the absolute configuration of this natural pheromone as $(4 R, 8 R)$, when they carried out the synthesis of all of the four possible stereoisomers of (1). Bioassays with the synthetic samples has shown that $(4 R, 8 R)$ and $(4 R, 8 S)$ are active isomers. Suzuki et al. ${ }^{5}$ later found that a mixture of these isomers in a ratio of 8:2 was about 10 times more active than $(4 R, 8 R)$ alone. Since identification of this structure, a number of racemic and stereoselective synthesis have been reported ${ }^{6,7}$. Some of them involve many steps with complex experimental procedures ${ }^{8,9}$. In this paper we

$\dagger$ in memoriam describe a very short synthesis of two of the isomers of 4,8-dimethyldecanal: $(4 R, 8 S)-(\mathbf{1 a})$ and $(4 S, 8 S)-(\mathbf{1 b})$ by connecting two chiral building blocks, in a synthetic route with only three steps and high overall yield (54\%) (Scheme $1)$.

\section{Results and Discussion}

Following the procedure of Varma ${ }^{10}$, the chiral citronellol (2) - (Aldrich, $97 \%$ e.e) and (2a) - (Aldrich, $67 \%$ e.e) were transformed into the known tosylates (3) and (3a) $)^{11}$ in $86 \%$ yield. Coupling of these compounds with a Grignard reagent prepared from $(S)-(+)-1$-bromo-2-methylbutane $^{12}(4)$ under the condition of Schlosser ${ }^{13}$ yielded the hydrocarbons (5) and (5a) in 77\%. Ozonolysis of (5) and (5a) in methanol-dichloromethane at $-78{ }^{\circ} \mathrm{C}$, followed by treatment with $\mathrm{DMS}^{14}$, afforded the desired pheromones (1a), $\left([\alpha]_{\mathrm{D}}+7.80^{\circ}, \mathrm{CHCl}_{3} ; \mathrm{lit}^{4}[\alpha]_{\mathrm{D}}+9.94^{\circ}, \mathrm{CHCl}_{3}\right)$ and (1b), $\left([\alpha]_{\mathrm{D}}+7.00^{\circ}, \mathrm{CHCl}_{3} ; \mathrm{lit}^{4}[\alpha]_{\mathrm{D}}+7.33^{\circ}, \mathrm{CHCl}_{3}\right)$ in $81 \%$ yield. The main advantage of the present approach is 

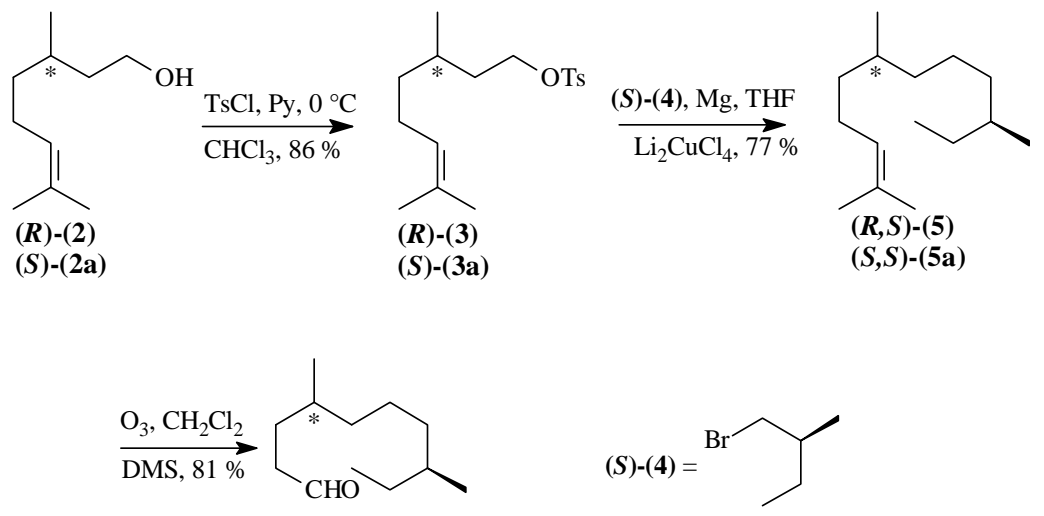

$(\boldsymbol{R}, S)-(\mathbf{1 a})$

$(S, S)-(1 b)$

Scheme 1. Synthesis of $(4 R, 8 S)$ - and $(4 S, 8 S)$ - 4,8-dimethyldecanal (1a) and (1b).

that no labile stereocenters are present, thus preventing racemization. The difference observed on the value of the optical rotation between our product $(4 R, 8 S)-(\mathbf{1 a})$ and that reported in the literature is the result of the low enantiomeric enrichment of $(S)$-citronellol (2a) used as starting material.

\section{Experimental}

The IR spectra refer to films and were measured on a Bomem M-102 spectrometer. The ${ }^{1} \mathrm{H}-\mathrm{NMR}$ spectra were recorded with TMS as an internal standard at $400 \mathrm{MHz}$ on a Brucker ARX 400 spectrometer. The ${ }^{13} \mathrm{C}-\mathrm{NMR}$ spectra were recorded with TMS as an internal standard at 100 $\mathrm{MHz}$ on a Brucker ARX 400. Optical rotation was measured on a Perkin-Elmer 241 polarimeter. CHN data were obtained in an EA 1108 CHNS-O Fisons Instrument. GCMS Analysis was carried out on a Shimadzu QP-5000 GC-MS spectrometer in a split injector mode. The DB-5 capillary column $(30 \mathrm{~m} \times 0.53 \mathrm{~mm} \times 0.25)$ was operated at $70{ }^{\circ} \mathrm{C}$ for $1 \mathrm{~min}$, increased to $270{ }^{\circ} \mathrm{C}$ at a rate of $7{ }^{\circ} \mathrm{C} / \mathrm{min}$ and held at this temperature for $10 \mathrm{~min}$. Column chromatography was carried out on columns packed with Merck Kieselgel 60, Art.-Nr. 7734.

(3R)-3,7-dimethyl-6-octenyl-4-methyl-1-benzenesulfonate (3)

$(R)$-Citronellol (2) $(2.0 \mathrm{~g}, 12.8 \mathrm{mmol})$ was dissolved in chloroform $(10 \mathrm{~mL})$ and cooled in an ice bath $\left(0{ }^{\circ} \mathrm{C}\right)$. Pyridine $(2.0 \mathrm{~mL}, 25.6 \mathrm{mmol})$ was then added, followed by addition of $p$-toluenesulfonylchloride $(3.65 \mathrm{~g}, 19.2 \mathrm{mmol})$ in small portions with constant stirring. The reaction was complete in $3.5 \mathrm{~h}$. Ether $(50 \mathrm{~mL})$ and water $(10 \mathrm{~mL})$ were added and the organic layer was washed successively with $\mathrm{HCl} 10 \%, \mathrm{NaHCO}_{3}$ sat, and water and then dried $\left(\mathrm{MgSO}_{4}\right)$. The solvent was removed under reduced pressure and the crude tosylate was column chromatographed (hexane / ethyl acetate: $8 / 2$ ) on a silica gel column yielding $3.0 \mathrm{~g}$ $(86 \%)$ of $(R)$ - (3). IR $\left(v_{\max }\right.$ film cm $\left.\mathrm{cm}^{-1}\right):=3032,2930,1597$,
1360, 1179, 948; ${ }^{1} \mathrm{H}-\mathrm{NMR}\left(400 \mathrm{MHz}, \mathrm{CDCl}_{3}\right)$ \&: $0.81(\mathrm{~d}$, $\mathrm{J}=6.4 \mathrm{~Hz}, 3 \mathrm{H}) ; 1.10-1.30(\mathrm{~m}, 2 \mathrm{H}) ; 1.40-1.55(\mathrm{~m}, 2 \mathrm{H}) ; 1.57$ $(\mathrm{s}, 3 \mathrm{H}) ; 1.67(\mathrm{~d}, \mathrm{~J}=1.2 \mathrm{~Hz}, 3 \mathrm{H}) ; 1.82-1.96(\mathrm{~m}, 2 \mathrm{H}) ; 2.45$ (s, 3H); 4.01-4.10 (m, 2H); $5.02(\mathrm{tq}, \mathrm{J}=1.2,7.2 \mathrm{~Hz}, 1 \mathrm{H})$; 7.34 (d, J = $8 \mathrm{~Hz}, 2 \mathrm{H}) ; 7.79$ (d, J = $8 \mathrm{~Hz}, 2 \mathrm{H}) ;{ }^{13} \mathrm{C}-\mathrm{NMR}$ $\left(100 \mathrm{MHz}, \mathrm{CDCl}_{3}\right) \delta: 17.5 ; 18.9 ; 21.5 ; 25.1 ; 25.6 ; 28.7$; $35.5 ; 36.5 ; 68.9 ; 124.2 ; 127.7 ; 129.7 ; 131.3 ; 133.0 ; 144.6$.

\section{(3S)-3,7-dimethyl-6-octenyl-4-methyl-1-benzenesulfonate} (3a)

In the same manner as described above, $(S)$-Citronellol (2a) was converted into tosylate (3a). The spectral data were identical with those of $(R)$ - (3).

$(6 R, 10 S)-(+)-2,6,10$-trimethyl-2-dodecene (5)

The Grignard reagent was prepared from bromide (4) $(4.40 \mathrm{~g}, 29.0 \mathrm{mmol})$ and magnesium $(0.72 \mathrm{~g})$ in dry THF $(12 \mathrm{~mL})$. This slurry was added dropwise to a solution of (3a) $(2.0 \mathrm{~g}, 7.2 \mathrm{mmol})$ in dry THF $(12 \mathrm{~mL})$ with stirring and cooling below $-60{ }^{\circ} \mathrm{C}$. A solution of $\mathrm{Li}_{2} \mathrm{CuCl}_{4}$ in THF $(0.1$ $\mathrm{M}, 0.37 \mathrm{~mL}$ ) was added to the mixture, and the temperature was gradually raised to room temp. After overnight stirring, the mixture was poured onto ice and ammonium chloride solution, and subsequently extracted with ether. The extract was washed with saturated $\mathrm{NaHCO}_{3}$ solution and brine, dried with $\mathrm{MgSO}_{4}$ and concentrated in vacuo. The residue was chromatographed on silica gel (hexane / ether : 9.5 / $0.5)$ to give the hydrocarbon (5) in $77 \%$ yield $(1.15 \mathrm{~g})$. $[\alpha]_{\mathrm{D}}^{25}=+7.96\left(c=7.30\right.$ in $\left.\mathrm{CHCl}_{3}\right)$; IR $\left(v_{\max }\right.$ film cm$\left.{ }^{-1}\right):=$ 2920, 1600, 1455, 1376, 1069; ${ }^{1} \mathrm{H}-\mathrm{NMR}(400 \mathrm{MHz}$, $\left.\mathrm{CDCl}_{3}\right) \delta: 0.84(\mathrm{~d}, \mathrm{~J}=6.4 \mathrm{~Hz}, 3 \mathrm{H}) ; 0.85(\mathrm{t}, \mathrm{J}=6.4 \mathrm{~Hz}, 3 \mathrm{H})$; $0.86(\mathrm{~d}, \mathrm{~J}=6.8 \mathrm{~Hz}, 3 \mathrm{H}) ; 1.00-1.15(\mathrm{~m}, 4 \mathrm{H}) ; 1.26-1.29(\mathrm{~m}$, $8 \mathrm{H}) ; 1.60$ (s, 3H); 1.68 (s, 3H); 1.90-2.00 (m, 2H); $5.11(\mathrm{t}$, $\mathrm{J}=6.4 \mathrm{~Hz}, 1 \mathrm{H}) ;{ }^{13} \mathrm{C}-\mathrm{NMR}\left(100 \mathrm{MHz}, \mathrm{CDCl}_{3}\right) \delta: 11.5 ; 17.6$; $19.2 ; 19.6 ; 24.5 ; 25.6 ; 25.8 ; 29.6 ; 32.4 ; 34.4 ; 36.9 ; 37.2$; 37.3; 125.1; 130.9; GC-MS (70 eV) $\mathrm{m} / z \%: 210\left(\mathrm{M}^{+}\right.$, 16.17), 140 (5.68), 125 (16.63), 111 (25.59), 97 (16.46), 83 
(35.42), 70 (100), 56 (92.00); (Anal. Calcd. for $\mathrm{C}_{15} \mathrm{H}_{30}$ : C, $85.83 \%$; H, 14.37\%. Found: C, 85.35\%; H, 14.44\%).

$(6 S, 10 S)-(+)-2,6,10$-trimethyl-2-dodecene (5a)

As described above, compound (3) was converted into hydrocarbon (5a). The spectral data were identical with those of $(R, S)-(5) .[\alpha]_{\mathrm{D}}{ }^{25}=+6.47\left(c=17.0\right.$ in $\left.\mathrm{CHCl}_{3}\right)$ (Anal. Calcd. for $\mathrm{C}_{15} \mathrm{H}_{30}$ : C, $85.83 \% ; \mathrm{H}, 14.37 \%$. Found: C, $85.75 \%$; H, 14.61\%).

\section{(4R, 8S)-(+)-4,8-dimethyldecanal (1a)}

To a solution of (5) $(1.0 \mathrm{~g}, 4.8 \mathrm{mmol})$ in methanol-dichloromethane $(2: 1,200 \mathrm{~mL})$ ozone was bubbled for 30 min at $-78{ }^{\circ} \mathrm{C}$. Dimethyl sulfite $(10 \mathrm{~mL})$ was added, and the reaction mixture stirred for another $10 \mathrm{~h}$ at room temperature. After concentration in vacuo, the residue obtained was chromatographed over silica gel (hexane / ethyl acetate : 7 / 3) affording $0.73 \mathrm{~g}$ of pheromone (1a) $(81 \%) \cdot[\alpha]_{\mathrm{D}}{ }^{25}$ $=+7.80\left(c=7.12\right.$ in $\left.\mathrm{CHCl}_{3}\right)$; IR $\left(v_{\max }\right.$ film cm$\left.{ }^{-1}\right): 2927$, 2718, 1727, 1462, 1381, 1126; ${ }^{1} \mathrm{H}-\mathrm{NMR}$ (400 MHz, $\left.\mathrm{CDCl}_{3}\right) \delta: 0.84(\mathrm{~d}, \mathrm{~J}=6.4 \mathrm{~Hz}, 3 \mathrm{H}) ; 0.85(\mathrm{t}, \mathrm{J}=6.8 \mathrm{~Hz}, 3 \mathrm{H})$; $0.88(\mathrm{~d}, \mathrm{~J}=6.4 \mathrm{~Hz}, 3 \mathrm{H}) ; 1.04-1.14(\mathrm{~m}, 3 \mathrm{H}) ; 1.20-1.35$ (m, $5 \mathrm{H}) ; 1.42-1.46(\mathrm{~m}, 2 \mathrm{H}) ; 1.63-1.69(\mathrm{~m}, 2 \mathrm{H}) ; 2.40-2.46(\mathrm{~m}$, $2 \mathrm{H}) ; 9.77(\mathrm{t}, \mathrm{J}=1.6 \mathrm{~Hz}, 1 \mathrm{H}) ;{ }^{13} \mathrm{C}-\mathrm{NMR}\left(100 \mathrm{MHz}, \mathrm{CDCl}_{3}\right)$

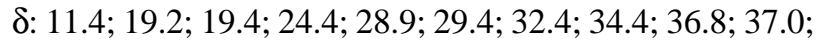
41.2; 203.0; GC-MS (70 eV) $\mathrm{m} / z \%: 140\left(\mathrm{M}^{+}-44,4.05\right)$, 125 (3.28), 111 (10.09), 85 (28.74), 70 (57.00), 57 (81.00), 43 (100); (Anal. Calcd. for $\mathrm{C}_{12} \mathrm{H}_{24} \mathrm{O}: \mathrm{C}, 78.20 \%$; $\mathrm{H}$, 13.12\%. Found: C, 78.14\%; H, 13.07\%).

(4S, 8S)-(+)-4,8-dimethyldecanal (1b)

As described above, compound (5a) was converted into pheromone (1b). The spectral data were identical with those of $(R, S)-(\mathbf{1 a}) \cdot[\alpha]_{\mathrm{D}}{ }^{25}=+7.00\left(c=9.15\right.$ in $\left.\mathrm{CHCl}_{3}\right)$ (Anal. Calcd. for $\mathrm{C}_{12} \mathrm{H}_{24} \mathrm{O}$ : C, $78.20 \%$; H, 13.12\%. Found: C, 78.29\%; H, 13.19\%).

\section{Acknowledgments}

The authors thank FAPESP and CNPq for financial support and fellowships.

\section{References}

1.Levinson, H.Z.; Mori, K. Naturwissenschaften 1983, 70, 190-192.

2. Suzuki, T. Agric. Biol. Chem. 1981, 45 (6) 1357-1363.

3. Suzuki, T. Agric. Biol. Chem. 1981, 45 (11) 26412643.

4. Mori, K.; Kuwahara, S.; Ueda, H. Tetrahedron 1983, 39 (14) 2439-2444.

5. Suzuki, T.; Kozaki, J.; Sugawara, R.; Mori, K. Appl. Entomol. Zool. 1984, 19, 15.

6. Breuer, E.; Deutsch, J.; Lazarovici, P. Chem. and Ind. 1982, 907.

7. Fuganti, C.; Grasselli, P.; Servi, S.; Högberg, H.-E. J. Chem. Soc., Perkin Trans. I 1988, 3061.

8. Schreiber, S.L.; Hullin, B. Tetrahedron Lett. 1986, 27, 4561.

9. Moinseenkov, A.M.; Ceskis, B.A. Dokl. Akad. Nauk SSSR 1986, 290, 1379.

10. Kabalka, G.W.; Varma, V.; Varma, R.S. J. Org. Chem. 1986, 51, 2386-2388.

11. Mori, K.; Wu, J. Liebigs Ann. Chem. 1991, 783-788.

12. Mori, K. Tetrahedron 1974, 30, 3817.

13. Fouquet, C.; Schlosser, M. Angew Chem. Int. Ed. Engl. 1974, 13, 83.

14. Chan, T.; Xin, Y. J. Org. Chem. 1997, 62, 3500-3504. 